\title{
LAS CARTAS Y DIARIOS DE GUATEMALA DE ANDRZEJ BOBKOWSKI COMO EJEMPLOS DE TRADUCCIÓN IN- TERCULTURAL. PROPUESTA DE UN NUEVO ENFOQUE TRADUCTOLÓGICO
}

\begin{abstract}
Kasperska Iwona, Las cartas y diarios de Guatemala de Andrzej Bobkowski como ejemplos de traducción intercultural. Propuesta de un nuevo enfoque traductológico. [Andrzej Bobkowski's letters and diaries from Guatemala as an example of intercultural translation. A new approach to translation]. Studia Romanica Posnaniensia, Adam Mickiewicz University Press, Poznań, vol. XXXVII/1: 2010, pp. 55-67. ISBN 978-83-232-2145-6. ISSN 0137-2475. DOI 10.2478/v10123-010-0005-3.

The aim of this paper is to introduce a new approach in translation studies which is an intercultural translation. Based on the methodology of Postcolonial Theory, the Manipulation School and Polysystem Theory, it allows for an analysis of texts originally written in the language of the target culture. Application of this new framework is exemplified by diaries and letters of a Polish writer, Andrzej Bobkowski.
\end{abstract}

\section{INTRODUCCIÓN}

Al introducir el concepto de traducción intercultural partimos de múltiples premisas que se ven arraigadas en distintas teorías de traducción, aparecidas en el siglo $\mathrm{XX}$. Nos apoyamos especialmente en los enfoques de carácter cultural e ideológico que contribuyeron de manera significativa en la cristalización de nuestra propuesta.

Antes que nada nos gustaría señalar tres importantes orientaciones, es decir la teoría poscolonial, la Escuela de la Manipulación y la teoría del polisistema, como las que nos inspiraron y nos dieron un impulso para estudiar de manera más sistémica la obra del escritor polaco, Andrzej Bobkowski. Más adelante nos adentraremos en los puntos de interés de los investigadores quienes, bajo el signo de los enfoques mencionados, tomaban en consideración el contexto de llegada, las políticas de publicación y divulgación de textos literarios y la recepción propiamente dicha, así como las cuestiones ideológicas que se inscriben en ellas.

En el análisis que nos proponemos llevar a cabo en este artículo, quisiéramos 1lamar la atención a los textos escritos originalmente en la lengua del público de llegada y marcados por una visión particular del Otro. En nuestro caso, se trata de la obra cuentística, diarística y epistolaria que fue concebida por Bobkowski durante su viaje a Guatemala, emprendido en 1948, con el objetivo de establecerse allí junto con su 
esposa, Barbara Birtus, y continuada posteriormente a lo largo de los años vividos en dicho país de América Central.

Nos damos cuenta del hecho de que la presencia de estos textos dentro de nuestro corpus pueda sorprender. Es precisamente el apartado siguiente el que incluirá una justificación de esta óptica y en el que nos vemos obligados de dar una explicación de los porqués de la introducción de este corpus dentro del contexto de la traducción, en el que ubicamos el análisis presentado a continuación.

\section{EL CONCEPTO DE LA TRADUCCIÓN INTERCULTURAL Y SUS BASES EPISTEMOLÓGICAS}

Entendemos como traducción intercultural, la traducción-explicación que se sirve de representaciones para enseñar el Otro al receptor de la cultura de destino. El término de representaciones lo debemos a la teoría poscolonial cuya metodología incluye el estudio de textos escritos por los dominantes (colonizadores) sobre los dominados (colonizados), llamados también subalternos. Las representaciones son imágenes del Otro que sustituyen una realidad objetiva por una realidad subjetiva, a fin de imponer y preservar la dominación del colonizador. En estas imágenes el Otro (no europeo) es presentado como buen salvaje, caníbal, bárbaro, pagano, oriental o sudesarrollado. Son los mitos reduccionistas los que ponen de relieve la existencia de una jerarquía de valores, sugieren una gradación de culturas, distinguen entre un supuesto centro y un supuesto margen (Carbonell i Cortés, 1997, p. 20).

En los textos (no solamente literarios) coloniales o neocoloniales, tales aspectos como el estilo, el lenguaje, la manera de presentar a los subalternos, la de hablar sobre ellos, el lugar donde transcurre la trama, la narración, el contexto histórico y social, constituyen los puntos estudiados por los "poscolonialistas" (Said, 2005, p. 55). En el análisis que sigue nos concentraremos en algunos de estos aspectos.

La teoría poscolonial hace hincapié en la necesidad de "descolonizar la manera de pensar de los europeos", aspira a la implantación de la historiografía, la literatura y el pensamiento del ser dominado, con el objetivo de anular los efectos del discurso colonial. Éste fue definido por Homi Bhabha como basado en

the concept of 'fixity' in the ideological construction of otherness. Fixity, as the sign of cultural/ historical/racial difference in the discourse of colonialism, is a paradoxical mode of representation [...] Likewise the stereotype, which is its major discursive strategy, is a form of knowledge and identification that vacillates between what is always 'in place', already known, and something that must be anxiously repeated [...]. (Bhabha, 1994, p. 66)

El estereotipo que implica ambivalencia como su rasgo característico, es un instrumento básico de la discriminación, el que obstaculiza o "hace imposible la transgresión de las limitaciones desde el espacio del Otro" (Bhabha, 1994, p. 67). Algunos ejemplos de esta práctica se notarán también en nuestro corpus. 
Otro enfoque que nos servirá de punto de referencia es la Escuela de la Manipulación que indaga sobre el papel de la casa editorial, sobre los criterios de la selección de libros que se publican y las posibles reacciones del público receptor. En el caso de Andrzej Bobkowski hay que hablar más bien de las casas editoriales y de los periódicos (en plural en ambos casos) que lanzaron sus escritos al mercado, tanto polaco como extranjero, en distintas épocas históricas (no nos podemos abstener de usar este sustantivo por más controvertido que pueda parecer).

Aparte de los mencionados aspectos de la actividad editorial que nos gustaría comentar más adelante, es indispensable hacer referencia al criterio de la propia manipulación del texto original (o de la cultura de partida). En este contexto es interesante la tesis de André Lefevere quien indica cinco restricciones (que son una expresión de la manipulación y, de hecho, la propician) bajo las cuales opera la literatura: el universo del discurso que incluye los conocimientos, objetos y costumbres de un periodo histórico al que se refiere el autor; la lengua natural (la del texto de partida); el patronazgo (o mecenazgo) que abarca las normas y estrategias impuestas, o sea, un control externo; la poética, es decir, la calidad literaria de la obra en cuestión; y el texto en sí con su ideología, su poética, sus convenciones, su género, su discurso y su lengua. El investigador belga subraya que toda reescritura (sea interpretación, crítica, antología, historia de literatura, o traducción) es sometida a una de estas restricciones, la cual implica otras. Cada reescritura, independientemente de su intención, refleja una ideología y cierta poética, desempeñando una función en la cultura dada (Carbonell i Cortés, 1999, pp. 200, 221-222).

Sin enfrascarnos demasiado en el concepto de reescritura, el que de por sí patentiza hasta qué punto las cuestiones ideológicas intervienen en la producción y la recepción de textos, cabe reiterar que, en los ojos de Lefevere, dicho fenómeno es una manipulación porque depende del poder (Lefevere, 1992, p. vii). Más adelante trataremos las instancias del poder en relación con el corpus, las circunstancias de la producción de textos en cuestión y, sobre todo, su divulgación.

La última teoría que merece ser mencionada en el contexto del producto y su recepción, es la del polisistema, propuesta por Itamar Even-Zohar y Gideon Toury. La metodología descriptiva que usan los representantes de esta escuela nos servirá para analizar la obra de Bobkowski, que no pretendemos evaluar o corregir, como si se tratara de la falta de reverencia ante lo políticamente correcto en los escritos del "hijo de Conrad". Lo que proponemos es, precisamente, una descripción del ideario del autor polaco, presentado en su obra, con la intención de escudriñarlo y descifrarlo desde la óptica de la teoría poscolonial.

Otro punto de los estudios polisistémicos que nos interesa es la tesis sobre la existencia de un centro, ocupado por la literatura nacional canónica, y una periferia, ocupada por la literatura de afuera (la nacional no canónica o la traducida). Nos gustaría detenernos un momento en este aspecto del funcionamiento de la obra de Bobkowski en la cultura receptora. Resulta que, en los escritos de este autor, quien 
emigró de Polonia a Francia en 1938 y, luego, de Francia a Guatemala en 1948, por lo que es considerado un autor "de la emigración polaca", se puede observar una interesante tendencia al desplazamiento de la periferia hacia el centro. Las fluctuaciones en el estatus de nuestro autor se deben al cambio del sistema político, que se produjo en Polonia después de la segunda guerra mundial (y provocó una "diglosia literaria" hasta 1989), a la decisión del autor de exiliarse en Guatemala y a la importancia del innegable centro de la cultura polaca en el extranjero, que fue el círculo de la revista parisiense, Kultura, bajo la dirección de Jerzy Giedroyc. Merece la pena recordar que, a principios de su actividad literaria (en los años 40 del siglo XX), Bobkowski publicó fragmentos de sus diarios en algunas revistas polacas editadas en el país como, por ejemplo, Tygodnik Powszechny o Nowiny Literackie. Tras el agudizamiento de su actitud anticomunista, no quiso ser publicado en la Polonia ya oficialmente socialista $\mathrm{y}$, en efecto, dejó de serlo ${ }^{1}$. Sin embargo, fue uno de los autores más codiciados por la Kultura parisiense ${ }^{2}$ y bastante bienvenido por otro baluarte de los literatos polacos exiliados, la revista londinense, Wiadomości. En el prólogo al conjunto de cartas Bobkowski - Giedroyc, y en la nota del editor a los diarios, $Z$ dziennika podróży, se subraya que, hasta 1994, ningún libro de Bobkowski fue publicado en Polonia en el mercado oficial (Zieliński, 1997, p. 5; Kądziela, 2008, p. 210). No obstante, a partir de aquel año hasta la fecha, podemos observar una eclosión del interés por la obra del admirador y "seguidor de Conrad" de la parte de las editoriales polacas. Basta echar un vistazo a estas publicaciones para llegar a la conclusión de que, desde hace varios años, la obra de nuestro autor es cada vez más divulgada:

1994 Opowiadania i szkice (cuentos y fragmentos de diarios), Oficyna Wydawnicza Interim

1997 Jerzy Giedroyc - Andrzej Bobkowski. Listy 1946-1961 (cartas), Instituto Literario de París, Universidad M. Curie-Skłodowska de Lublin

1998 Coco de Oro. Szkice i opowiadania (cuentos, fragmentos de diarios, un artículo crítico)

2003 Przysiagtem sobie, że jeśli umrę, to nie $w$ ttumie... Korespondencja z Aniela Mieczysławska, 1951-1961 (cartas), Wydawnictwo Ruta

Szkice piórkiem (diarios), Instituto Literario de París, Editorial CiS

2006 Z dziennika podróży (diarios), Biblioteka Więzi

Listy do Tymona Terleckiego 1956-1961 (cartas), Biblioteka Więzi

${ }^{1}$ En sus cartas a Jerzy Giedroyc, reunidas por Jan Zieliński (1997), el autor de Coco de Oro expresa sin rodeos su desdén hacia los intelectuales polacos "de adentro" quienes, para ser publicados, escribían bajo el dictamen el gobierno comunista, y hacia los "de afuera" quienes, procurando ser publicados en su país natal (y sin tener mucha posibilidad de divulgar su obra en el extranjero), estaban dispuestos a "rajarse". Véase, por ejemplo, la carta del 22 de noviembre de 1955 o del 12 de noviembre de 1956.

${ }^{2}$ Un $90 \%$ de toda la obra de Bobkowski fue publicado en la revista Kultura o por el Instituto Literario de París, en la serie "Biblioteka Kultury" (Zieliński, 1997, p. 12). 
2007 Zmierzch i inne teksty (cuentos y ensayos), Biblioteka Więzi

2008 Punkt równowagi (cuentos), Wydawnictwo Literackie

Listy z Gwatemali do matki (cartas), Wydawnictwo Książkowe Twój Styl

2009 Ikkos $i$ Sotion oraz inne szkice (ensayos), Biblioteka Więzi

(El 12 de octubre de 2009 va a ser publicado un libro de cartas de Bobkowski a Jarosław Iwaszkiewicz)

De las fechas y el contenido de los libros mencionados resalta la repetitividad, el empeño de disfrazar los mismos textos (cuentos y diarios) con otras portadas y títulos algún tanto distintos, y el apuro en publicar toda la obra epistolaria de Bobkowski. Desde luego, esta política editorial, por más incoherente que parezca, contribuye a la divulgación de la escasa, dicho sea de paso, obra bobkowskiana, silenciada durante decenios y apenas conocida por un público restringido a investigadores y universitarios.

Tal vez parezca demasiado pronto constatar que la obra de nuestro autor se haya establecido en el centro del sistema literario polaco, pero ya podemos indicar ciertas premisas que parecen estar obrando a favor del desplazamiento de la obra de Bobkowski desde la periferia hacia el centro. Una de ellas es, precisamente, dicha conmoción en el mercado editorial polaco, luego el apoyo de la revista Kultura y la autoridad del propio Giedroyc ${ }^{3} \mathrm{y}$, finalmente, la ferviente discusión sobre el canon de la literatura polaca nacional, que se sigue llevando a cabo en Polonia desde hace algunos años.

Con todo, la pregunta que nos hacemos es hasta qué punto este posible y probable nuevo estatus de Bobkowski va a influir en la recepción de su obra, es decir en la "verosimilitud" de su ideario y sus interpretaciones-traducciones de la cultura guatemalteca.

Ahora bien, retomemos nuestra definición de traducción intercultural y la cuestión del corpus. Al estudiar varios textos escritos en castellano, pero pertenecientes a otras culturas diferentes a la española, nos dimos cuenta de que cuando es la cultura la que constituye una unidad de traducción, no importa que el texto de llegada no sea una traducción interlingüística.

Pongamos por caso la obra de los cronistas o conquistadores españoles que describen el Nuevo Mundo, o sea una realidad ajena a la suya, en función de los receptores (indicados explícitamente por los mismos autores) que sabemos que eran principalmente los reyes de España. La obra de estos autores fue concebida en la misma lengua que la que dominaban los receptores, y su objetivo fue dar a conocer, dar cuenta, explicar, justificar, pero también manipular, influir y "representar" para lograr sus fines de distinta índole y no siempre expresada de manera explícita. Así, esta traducciónexplicación del Nuevo Mundo se producía a través del idioma del receptor.

${ }^{3}$ En múltiples cartas íntimas Bobkowski "se queja" a los destinatarios diciendo que Giedroyc insiste en enviarle algún texto. "El Príncipe" estaba convencido de que el autor de Szkice piórkiem era un genio literario (Zieliński, 1997, p. 8). 
Además, desde la perspectiva de varios centenarios durante los cuales se estuvo estudiando estas crónicas y cartas, aplicándoles distintas metodologías, sabemos también hasta qué punto dichos textos originales contribuyeron en fijar imágenes distorsionadas, estereotipos y respresentaciones en las mentes europeas. Las repercusiones que tuvo el concepto del buen salvaje, por ejemplo, no requieren ningún comentario adicional.

Por otra parte, los textos mencionados incluyen un sinnúmero de pasajes escritos en lenguas vernaculares de las tierras conquistadas (listas de vocabulario, nombres propios y comunes, ilustraciones con inscripciones) como, por ejemplo, los incluidos en la Historia General de las Cosas de la Nueva España de fray Bernardino de Sahagún. La conclusión que podemos sacar de este ejemplo y del de Bobkowski es que el autor que escribe sobre otra cultura no puede pasar por alto la lengua que la representa.

A nuestro parecer, en el caso de la obra "guatemalteca" de Bobkowski tenemos que ver con otro ejemplo de traducción intercultural, el que incluye también la interlingüística, lo que ejemplificaremos a continuación.

\section{BOBKOWSKI COMO TRADUCTOR DE CULTURA}

El autor-traductor Bobkowski se encuentra entre dos universos, tanto discursivos como culturales. Su estrategia de traducción consiste en recurrir a explicaciones, comparaciones, transferencias, explicitaciones, definiciones, anécdotas, toda serie de referencias, citas y alusiones a la cultura y la literatura, etc., cuyos algunos ejemplos incluye nuestro análisis. Bobkowski escribe en polaco, salpicando sus textos de tantas intervenciones en lenguas extranjeras (no solamente en castellano, sino también en francés, alemán, latín y ruso) que este rasgo de su estilo no puede pasar inadvertido por el lector ${ }^{4}$. Además, sus procedimientos de familiarización y los de extrañamiento son instrumentos ideológicos, definidos (en referencia a las notas del traductor) por Ovidi Carbonell i Cortés como los que

subrayan la distancia entre culturas y confieren al traductor la potestad de «guía», de cicerone cultural que «explica», desde el raciocinio y el sentido común, una cultura ajena y sus aspectos ocultos. (Carbonell i Cortés, 1999, pp. 260-261)

El uso de los mencionados procedimientos de traducción intercultural permiten escudriñar el discurso de Bobkowski y dan la oportunidad de darse cuenta de sus interpretaciones de la realidad guatemalteca. Los ejemplos que seleccionamos para este análisis fueron regrupados de manera que destaca algunas de las múltiples facetas de aquella realidad, filtradas por la mirada ideológica del autor.

\footnotetext{
${ }^{4}$ Este rasgo de estilo de Bobkowski fue ridiculizado por Czesław Miłosz, por ejemplo, quien despreciaba a aquél como escritor (apud Kowalczyk, 2003, p. 21).
} 


\section{Filtro europeo}

Teraz, na tych ulicach, wśród tych ludzi na pewno mniej „kulturalnych” i ,intelektualnych” w znaczeniu europejskim, ale za to o ile mniej zbaraniałych i utrzodnionych, widzę ciagle te ogonki pokornych obywateli rewolucyjnej i indywidualistycznej Francji [...]. (agosto-diciembre de 1949, "Na tyłach", in: Coco de Oro, 1998, p. 76)

Los comillas que el autor usa en esta cita expresan su propio punto de vista, o sea su escepticismo ante la realidad europea, una vez terminada la segunda guerra mundial. Para Bobkowski Europa traicionó sus ideales y sus valores, se rindió ante el nazismo y el estalinismo, es decir, ante los totalitarismos que Bobkowski odiaba y que veía igualmente peligrosos. No obstante, los guatemaltecos ("ci ludzie") fueron ubicados por el autor a un cierto nivel y dentro de la jeraquía establecida por él, están ocupando una posición inferior respecto a Europa. A pesar de ser "mniej zbaraniali i utrzodnieni" (rasgos aparentemente positivos para el autor), la frase citada rastrea una sensación de "reconocimiento con restricciones". Es difícil no ver en este fragmento una crítica implícita de los que son menos "zbaraniali i utrzodnieni", porque en realidad, el hecho de que sean así, no quiere decir que sean como los europeos "en sus mejores tiempos", como decía Bobkowski y como se puede ver en la cita siguiente:

Europa to przede wszystkim jej człowiek, a - trudno i darmo - gatunek tego człowieka psuje się ostatnio z zatrważająca szybkością. Europejczyk zmienia się w pacotille, w barana, traci wszystkie te cechy, które stanowiły o jego wyższości dawniej: przedsiębiorczość, pęd do rozsądnego ryzyka, zdolność indywidualnego sądu, rozsądne posłuszeństwo. ("Na tyłach", in: Coco de Oro, p. 77)

Dicha frase expresa una crítica directa y aguda de la Europa de los años 40 del siglo XX, pero, implícitamente, sugiere su superioridad. Ahora bien, ¿la superioridad en comparación con quién? ¿Con qué Bobkowski está comparando a Europa si no con América o Guatemala? Las cualidades que enumera y que, en general, lo impresionan, son las que los guatemaltecos poseen raras veces. Es uno de los problemas que el autor plantea en varias ocasiones, comentándolo de tono burlón, amarga o irónicamente.

Sin embargo, a veces podemos tener la impresión (insistimos en lo efímero de la palabra) de que Bobkowski está tomando parte de los autóctonos:

Świat, nowy świat, trzeci świat. Mówi o nim się mało, pokpiwa z Gwatemal, Kostaryk, San Salvadorów i innych Hondurasów, a co się o nich wie? Przebogaty obszar, wielki i otwarty, pełen swobody i jeszcze ciagle najlepszych tradycji Europy. Kto wie, czy jej duch nie przetrwa właśnie tu i nie zaowocuje na nowo? (agosto-diciembre de 1949, "Na tyłach", in: Coco de Oro, 1998, p. 80)

En este ejemplo se nota que, para el autor, Europa, a pesar de su abierto desdén hacia dicho continente, expresado en la página posterior del diario, sigue siendo su punto de referencia. Bobkowski lo ve todo desde la perspectiva europea, sugiriendo que los guatemaltecos deben aspirar a algo más, y la mejor de las soluciones es aspirar a lo europeo. 
El discurso de Bobkowski está repleto de contradicciones, carece de consecuencia $\mathrm{y}$, antes que nada, abunda en emociones. $\mathrm{Al}$ analizar sus consideraciones respecto a Europa, al conocer su propio punto de vista y al darse cuenta del filtro europeo que usa, podemos enterarnos de su actitud hacia los guatemaletcos y la justificación de ésta.

\section{Filtro de "mitos" literario-cinematográficos}

Las reflexiones del autor, incluidas en el diario, $Z$ dziennika podróży, son de cabal importancia para este análisis. El transatlántico "Jagiełło" que Bobkowski y su esposa, Barbara, embarcaron en Cannes, pasa por Cartagena, Colombia. Durante el viaje: "zatracam poczucie rzeczywistości, myślę ilustracjami z Robinsona Crusoe, z Dzieci kapitana Granta" ( $Z$ dziennika podróży, p. 123). A continuación del mismo texto aparece una referencia a La Vorágine de José Eustasio Rivera, la novela cuya protagonista es la selva. Este tipo de observaciones destacan el hecho de que la descripción de América Latina es llevada a cabo a través de la confrontación del "saber" previo con la realidad (vista por primera vez, dicho sea de paso). En esta práctica vemos un problema muy grave. Es que el lector olvida a menudo que el "saber" en cuestión tiene sus raíces en la ficción literaria. Éste el caso de los diarios de Bobkowski.

El filtro de "mitos" lo hace recurrir a las comparaciones en las que encontramos referencias a su bagaje cultural. La frase: "Nastrój, kolor, styl domów i domków są takie, jak w kowbojskich filmach" ( $Z$ dziennika podróży, p. 128), puede ser un ejemplo.

\section{Filtro racial}

En varias ocasiones nuestro autor subraya que no está libre de prejuicios racistas. No obstante, en estas declaraciones encontramos fórmulas de evidente carácter racista. Cuando Bobkowski comenta el desfile del comunismo en América Latina, con el énfasis en el caso guatemalteco, y critica severamente las manipulaciones y jueguitos que, en su opinión, usan los comunistas, con el fin de agudizar las tensiones raciales. El autor cree que el comunismo, en su variedad moscovita, tiende a "rozbicie cywilizacji białego człowieka". A Bobkowski le da pena un "jeszcze w dziewięciu dziesiątych Indianin", el complejo de "niedobieleni" (las comillas del autor) de millones de personas a quienes el comunismo quiere liberar por medio de sus "jueguitos".

La más curiosa es la constatación de que los comunistas intentan despertar el racismo entre los blancos ("Rozbudzając rasizm i kolorowe nacjonalizmy, stara się [Moskwa] rozbudzić rasistowską reakcję po naszej [białej] stronie. Jeśli nie wytrzymamy nerwowo, możemy łatwo zginąć."), como si esta actitud hacia el Otro hubiera sido algo anteriormente ausente en los blancos. Con un tono burlón e irónico Bobkowski comenta el nacimiento de la conciencia de raza o el orgullo de raza entre los indígenas, "czekoladowi tubylcy" (la calificación del autor). Llama esta práctica de los comunistas una "taktyka doskonale przemyślanej prowokacji wobec białego, wobec budowniczego całej cywilizacji zachodniej” (2006, p. 156 y siguientes). 
La superioridad del blanco como la tesis número uno de los escritos de Bobkowski está asentada, como las demás teorías del autor, en la escritura y la reescritura colonial. Veamos un fragmento del diario, titulado "Z notatek modelarza":

20 czerwca 1954

(...) Myślę o nich [Gwatemalczykach] i myślę już po raz nie wiem który, że Kali i Nel zaczęli szanować Stasia Tarkowskiego od momentu, w którym najpierw zastrzelił lwa, a potem Beduinów. Gdy myślę o przyszłości naszej cywilizacji, o Kalich, którzy spoglądają na nią ze wszystkich części świata, wydaje mi się, że ten jeden epizod z W pustyni $i$ w puszczy jest wspaniałym skrótem istoty zagadnienia. Szkoda, że [sąsiad] Toynbeego nie przeczytał. Nie - nie jesteśmy tylko jedną z wielu, z tych dwudziestu kilku cywilizacji, które minęły. To jednak coś więcej i może warto tego bronić, bo nic się w tym nie skończyło. Raczej dopiero zaczyna. ( $Z$ dziennika podróży, p. 164)

Durante la contienda en la Ciudad de Guatemala, en junio de 1954, Bobkowski quiere solo declarar la guerra a los comunistas (que en aquel momento están en el poder) "choćby dlatego, że czuję się kawałkiem tej cywilizacji, której tu na tym malutkim skrawku ziemi wypowiedziano otwartą walkę. Wcale nie jako Polak i nie jako biały" (2006, p. 163). Difícil confiar en la sinceridad de estas palabras mientras que en la página siguiente leemos un pasaje sobre Staś Tarkowski. Esta referencia es sumamente interesante porque la canónica, y muy inspiradora para Bobkowski, novela de Henryk Sienkiewicz, constituye un emblemático ejemplo del discurso colonial 5 .

$\mathrm{Al}$ continuar sus reflexiones sobre el comunismo y el papel del hombre blanco en su divulgación, Bobkowski concluye con las siguientes palabras:

18 lipca 1954

(...) Jesteśmy skłonni traktować komunizm jako jedną całość, en bloc, z punktu widzenia przede wszystkim białego, człowieka cywilizacji białej. Wydaje nam się, że działanie komunizmu na inną rasę i rozbudowa komunizmu wśród innych ras musi przebiegać podobnie jak wśród nas. Tymczasem teraz widzę, do jakiego stopnia komunizm jest wytworem białego, pokurczem naszej własnej cywilizacji. [...] My do wielu wymagań komunizmu jesteśmy zaprawieni od wieków dzięki chrześcijaństwu, człowiek kolorowy tego treningu nie posiada. Zmysł solidarności, dyscypliny, ultrapurytańskiej moralności w pewnych dziedzinach jest im obcy. Są miękcy, poddają się, ale nieraz z wciaggającą właściwością ruchomego piasku. Wśród kolorowych komunizm narażony jest ciągle na zupełnie nieoczekiwane „dzwonienie, kiedy im się podoba”. (Z dziennika podróży, pp. 173-174)

En una palabra, Bobkowski confirma que el hombre blanco es el responsable de la invención y la propagación del comunismo y que, afortunadamente, logró también crear un mecanismo de defensa contra esta "enfermedad". Resulta que los "kolorowi" no son capaces de hacer lo mismo. ¿Acaso no es este "dzwonienie, kiedy im się podoba" su mecanismo de defensa? El autor añade en la misma página que está contemplando el fenómeno desde la perspectiva de un hombre blanco y sus conclusiones sa-

${ }^{5}$ Qué difícil abstenerse del comentario sobre los paralelos entre los escritos de Sienkiewicz y los textos guatemaltecos de Bobkowski y respectivas actitudes de los autores. Lo declaramos públicamente y nos reservamos el derecho a hacerlo en otra ocasión. 
cadas de la observación de los "kolorowych" o "kolorowo-biali" resultan "najczęściej mylne" ("Z notatek modelarza", p. 174). Esta constatación tiene un peso significativo dentro del contexto de los escritos del "hijo de Conrad", quien comparte con el lector sus argumentos sobre la realidad circundante, con la restricción de que exista el filtro del hombre blanco, del que Bobkowski no puede desembarazarse.

El siguiente ejemplo concierne a los indígenas, los subalternistas de América Latina, quienes pertenecen al grupo excluido de sujetos que, según la teoría poscolonial, no tienen acceso a los foros en los que su voz fuera escuchada.

2 czerwca 1954

(...) Wprawdzie od roku usamodzielniłem się, przestałem już być białą nędzą, wyzyskiwaną przez kolorowych (figurez-vous, mon cher...) i żyję już tylko z moich modeli, ale trzeba znowu skoczyć naprzód. (“Z notatek modelarza”, in: Coco de Oro, 1998, p. 199)

Es muy significativa la frase en francés, intercalada entre paréntesis, despúes de "wyzysk przez kolorowego". Con ella el autor subraya que el fenómeno está fuera de la norma. El fragmento más abundante en este tipo de análisis social es el que presentamos a continuación:

\section{2 czerwca 1954}

(...) Specjalna kasta ci tutejsi właściciele sklepów i bogaci (ricos). Są leniwi i bez żadnej inicjatywy, bez wynalazczości. Bierność, a równocześnie kolorowa podstępność i przebiegłość $\mathrm{z}$ dodatkiem absolutnie doskonałego zmysłu naśladownictwa. Teraz już kręcą się koło mnie, nawet kłaniają się na ulicy, podpatrują, i w uśmiechach ich, gdy wyrażają obleśnie uznanie, czai się zawiść. Widzą nagle, że to „poszło”. Ale dostrzegają wynik i tylko wynik. Do dostrzeżenia łańcucha równań układanych w nieludzkim wysiłku, które doprowadziły mnie do tego skromnego wyniku, nie są zdolni. To jeszcze jeden $\mathrm{z}$ tych białych extranjeros, który ich oszukał. Oszukał ich pracowitością i rzutnością tak, jak nas oszukiwali kiedyś Niemcy, a potem Żydzi. Gdy siedziałem w którymś z ich sklepów za nędzne sto dolarów miesięcznie i byłem dobrym pracownikiem, gdy dawałem się wyzyskiwać, wszystko było w porządku. Byłem nieszkodliwy i potrzebny. Natomiast teraz to co innego.

Rozumiem ich i nie dziwię się im. Bezustanny kompleks niższości, lenistwo, brak inicjatywy i przedsiębiorczości powodują zawiść i nienawiść, podsycają ślepy nacjonalizm. ("Z $Z$ notatek modelarza", in: Coco de Oro, 1998, p. 200)

Esta „cita muestra cómo Bobkowski usa el discurso colonial y neocolonial, ubicando así al blanco (guatemalteco o extranjero) en oposición a los "de color" o indígenas. El escritor polaco repite los estereotipos (un procedimiento básico del discurso colonial) atribuyéndoles rasgos de carácter negativos (repetidos varias veces), que de manera unívoca califican peyorativamente los guatemaltecos: pereza, falta de cualquier iniciativa, de ingeniosidad y de invención, pasividad, astucia, perfidia de color y constante imitación. Su contrapunto lo constituye el extranjero, al que aquéllos le atribuyen la corrupción y la deshonestidad. Bobkowski ironiza adoptando la "postura" de un indígena que está persuadido de que los extranjeros "oszukują ich pracowitością i rzutkością". La frase: "Gdy siedziałem w którymś z ich sklepów za nędzne sto dolarów miesięcznie i byłem dobrym pracownikiem, gdy dawałem się wyzyskiwać, 
wszystko było w porządku. Byłem nieszkodliwy i potrzebny”, muestra que para Bobkowski, la explotación y la deshonestidad están relacionados con la raza en vez de constituir unos vicios humanos). El indígena es perezoso y carece de iniciativa, los mestizos son los "ricos" que explotan, y sus contrincantes llenos de iniciativa y muy emprendedores son los blancos. Así Bobkowski nos "ordena" a los lectores la realidad guatemalteca.

Volvamos a la cita. Merece la pena fijarnos en la frase: "Rozumiem ich i nie dziwię się im". Al leer esta declaración podemos llevarnos la impresión de que ahora mismo, en el mismo párrafo, o el que sigue, Bobkowski vaya a proporcionanos unas bases históricas o psicológicas de estas relaciones sociales. En vez de esto, revuelve el motivo del "bezustanny kompleks niższości" con el que se quiere explicar un hecho social de carácter eminentemente histórico, y justo después, nos "deleita" otra vez con una serie de cuantificadores racistas: "lenistwo, brak inicjatywy i przedsiębiorczości".

Recordemos a Bhabha quien dice que en el discurso colonial, el estereotipo con su repetitividad, su ambigüedad y su popularidad, es una "forma de saber e identificar" (1994, p. 66). Agreguemos que el procedimiento es peligroso y contagioso. La reescritura de Bobkowski tiene una dimensión social y algunas pruebas de eso las encontramos, por ejemplo, en los prólogos a las antologías que analizamos y cuyos autores retoman el discurso colonial del autor que exaltan y elogian: "małe środkowoamerykańskie państewko", "drugi Robinson", "nie całkiem ucywilizowany kraj”, "wszczepiać młodym Gwatemalczykom zasady demokracji, kultury i wolnego rynku" (Zieliński 1997); "stwarzać swym pracownikom Indianom ludzkie warunki i opiekować się nimi” (Czapski 1998), "egzotyczny kraik", "odruchowo czuł się przedstawicielem kultury zachodniej”, "misjonarz cywilizacji”, "kształtował dusze, rozbudzał w nich ambicje, wtajemniczał w kulturę techniczną i przyuczał do elementarnej kultury duchowej”, "odludzie", "eksperyment gwatemalski” (Terlecki 2006), "obca pozaeuropejska formacja kulturowa", "cenne obserwacje z życia codziennego pohiszpańskich krain amerykańskich" (Odojewski 2008). Esta lista no es sino una muestra y una prueba de cómo Bobkowski moldeó la actitud de los receptores, inclusive los llevó a sacar conclusiones muy atrevidas sobre su actitud ante la cultra guatemalteca ${ }^{6}$.

\section{Filtro lingüístico}

En la carta a su madre, Stanisława Bobkowska, fechada a 11 de diciembre de 1950, el escritor declara que el castellano no le gusta como lengua, lo que constituye un obstáculo en llegar a dominarlo bien. Sin embargo, la frecuencia con la que recurre al español en sus cartas, puede sugerir que lo hubiera dominado suficientemente para que algunos conceptos culturales tuvieran para él su mejor expresión en castellano precisamente. A título de ejemplo veamos el fragmento siguiente:

[...] zrozumiałem dopiero to genialnie podchwycone przez Keyserlinga określenie ,gana”. Gana to jakby po naszemu „ochota”. Ale nasza ochota jest czymś mimo wszystko bardziej określonym i precyzyjnym w porównaniu z ,ganą”. Po hiszpańsku mówi się: „yo tengo ganas

\footnotetext{
${ }^{6}$ Véase el prólogo de Kowalczyk a Przysiagłem sobie, że jeśli umrę, to nie w thumie... (2003).
} 
de bailar” = jakby „mam fantazję tańczyć”. Ta „gana” wyłazi tu ze wszystkiego. Najbardziej dokładnym określeniem terminu jest „mañana”, czyli „jutro”. Wszystko jest „jutro”. (1997, p. 34)

En este pasaje Bobkowski traduce al polaco dos palabras que, en su opinión, se refieren a los conceptos difíciles de tranferir a otra lengua y cultura, las del receptor que, en este caso, es Giedroyc. A estas palabras culturales hay que agregar rancho, finca, impracticable, y un sinfín de intercalaciones en francés, menos en alemán, y relativamente pocos en inglés. Éstos no son explicados, como si el autor considerara a sus lectores por lo menos trilingües.

\section{CONCLUSIÓN}

En el caso de Bobkowski, el saber adquirido in situ sobre la cultura guatemalteca, aumenta la confianza de la parte del lector y hace que el contenido de cartas y diarios parezca verosímil. Por un lado, es la confianza al emisor que escribe una carta íntima (a su madre, a sus amigos, a sus confidentes) por lo que se supone que es abierto y sincero. Por otro lado, es la confianza en la persona que sabe más y mejor que nosotros, por conocer la realidad guatemalteca desde muy cerca. Estas dos presuposiciones son naturales y en cierto sentido automáticas. Lo que tiene gran importancia es que los lectores nos olvidamos del "yo" del autor, de su experiencia personal y puntual, de sus filtros, y tendemos a tratar al autor como experto y conocedor. El muy posible movimiento de la periferia hacia el centro en el caso de los escritos de Bobkowski probablemente va a aumentar la confianza del lector quien, con buena fe, va a tratar estos textos como fuentes fidedignas.

En la obra epistolar y diarística de Bobkowski se manifiestan varios filtros de los cuales comentamos sólo algunos: el filtro europeo, el filtro literario-cinematográfico, el filtro racial y el filtro lingüístico. En relación con los autores-viajeros, Edward Said dice que analizan lo "maravilloso" de las tierras que visitan, destacan fenómenos que, según ellos, están fuera de la norma (la suya, la de su cultura, la europea), y llevan consigo en sus viajes sus propias mitologías (2005, p. 264). En el caso de Bobkowski tenemos que ver con este tipo de mitología en la que se inscriben sus presuposiciones respecto a Guatemala, o con los mitos literarios ya que fue la literatura la que lo inspiró a escoger este país como el lugar de exilio (más precisamente, se trata de la novela Nostromo de Joseph Conrad).

En resumidas cuentas, al pasar la realidad guatemalteca por los filtros Bobkowski efectúa una domesticación de fenómenos locales, de los valores que los autóctonos tienen en boga, de sus puntos de vista, lo cual se manifiesta en la constante evaluación de la cultura de partida. Sus filtros constituyen sus normas y son para él el mayor punto de referencia. De ahí que la domesticación resulte la estrategia de predilección de Bobkowski y la cultura guatemalteca en sí forma la unidad de su traducción. 


\section{BIBLIOGRAFÍA}

Bhabha H.K. (1994). The Location of Culture. Londres-Nueva York: Routledge.

Bobkowski A. (1997). Jerzy Giedroyc - Andrzej Bobkowski. Listy 1946-1961. Warszawa: Czytelnik.

- (1998). Coco de Oro. Szkice i opowiadania. Lublin: Towarzystwo Opieki nad Archiwum.

- (2006). Z dziennika podróży. Warszawa: Biblioteka Więzi.

- (2006). Listy do Tymona Terleckiego, 1956-1961. Warszawa: Biblioteka Więzi.

- (2008). Listy z Gwatemali do matki. Warszawa: Wydawnictwo Książkowe Twój Styl.

Carbonell i Cortés O. (1997). Traducir al Otro: traducción, exotismo, poscolonialismo. Cuenca: Ediciones de la Universidad de Castilla-La Mancha.

- (1999). Traducción y cultura. De la ideología al texto. Salamanca: Colegio de España.

Czapski J. 1998 (1961). Querido Bob. En Coco de Oro. Szkice i opowiadania. Lublin: Towarzystwo Opieki nad Archiwum Instytutu Literackiego w Paryżu, UMCS.

Kądziela P. (1994). Nota edytorska. In A. Bobkowski, Opowiadania i szkice. Warszawa: Interim.

Kowalczyk A.S. (2003). Słowa, rzeczy, życie. Świat według Bobkowskiego. En A. Bobkowski, Przysiagłem sobie, że jeśli umrę, to nie w ttumie... Korespondencja z Aniela Mieczystawska, 1951-1961. Wałbrzych: Wydawnictwo Ruta.

Lefevere A. (1992). Translation, rewriting, and the manipulation of literary fame. Londres: Routledge.

Odojewski W. (2008). Andrzej Bobkowski - nowa młodość. En A. Bobkowski, Listy z Gwatemali do matki. Warszawa: Wydawnictwo Książkowe Twój Styl.

Said W.E. (2005). Orientalizm. Trad. de M. Wyrwas-Wiśniewska. Poznań: Zysk i S-ka.

Terlecki T. (2006). Andrzej Bobkowski. En A. Bobkowski, Listy do Tymona Terleckiego, 1956-1961. Warszawa: Biblioteka Więzi.

Zieliński J. (1997). Kronika walki. En Jerzy Giedroyc - Andrzej Bobkowski. Listy 1946-1961. Warszawa: Czytelnik. 